\title{
The Hypocrisy in our Democracy: Placing Youth Voting in Perspective
}

By Brendon Legault

\begin{abstract}
In 2002 the Alberta Court of Queen's Bench dismissed a lawsuit brought by two women who had been denied the right to vote in an Alberta election. The court laid out several different justifications for the limiting the franchise to those under the age of 18. However, upon analysis, those justifications fail to withstand critical reasoning. Placing the courts reasoning in wider perspective exposes a great deal about the nature of Canada's political system today.
\end{abstract}

On October 31, 2002 the Supreme Court of Canada struck down a ban within the Canada Elections Act that prevented prison inmates from voting in federal elections. ${ }^{1}$ This resulted in the latest extension of the franchise to a new section of the Canadian population. Such extensions have been numerous, if not always prompt, throughout the history of Canada's electoral system. Indeed, voting rights are, perhaps, the sole aspect of our system which we have consistently been able to reform. This is not without good reason. While the franchise represent merely one portion of a diverse set of issues that describe the Canadian political system, there can be little doubt that the question of "who can vote" is a litmus test through which any democracy must be examined. The franchise, its extension, or its denial to a particular group will affect all aspects of the political system. Indeed, this fact has always been the primary justification for not permitting certain groups to exercise this right. With this significance in mind, we will examine a recent court case in Alberta, in which two young women -- aged 16 and 17 -- sued the provincial government for denying them the right to vote based on their age. In this case, Fitzgerald v. Alberta, the court found the voting age limit did violate their democratic and equality rights, but did so justifiably under Section 1 of the Canadian Charter of Rights and Freedoms. Ignoring the peripheral issues of legal technicality or the propriety of judicial policy making, we will examine the so-called "common sense" justifications which the court noted in upholding the ban-namely: the lack of experience and knowledge of the political system of most persons under 18, and their supposed difficulty forming rational decisions when voting. These arguments expose a wider range of concerns about the nature of our system when placed in the larger political context. The denial of the franchise, and a critical examination of the justifications for doing so, expose a great deal about not only the franchise itself, but of the wider range of issues that affect the system as a whole.

In the Fitzgerald ruling, Justice Lefsrud conceded an important point: every individual matures differently. Due to this fact any age restriction, by nature, will exclude certain individuals that are otherwise capable of making rational political decisions. ${ }^{2}$ It must also be recognized that we draw similar lines in several areas of public policy. However, this does not immunize such distinctions from critical scrutiny. Justice Lefsrud based his conclusions on an "obvious" need for at least some age restrictions in order to prevent a situation where a baby, for example, would be entitled to cast a vote in an election. Without disagreeing with this premise, it

\footnotetext{
${ }^{1}$ Sauvé v. Canada (Chief Electoral Officer), SCC 68 (Supreme Court of Canada 2002) http:// www.canlii.org/en/ca/scc/doc/2002/2002scc68/2002scc68.html4 (10 February 2011)

${ }^{2}$ Fitzgerald v. Alberta. 331 SCC 1086 (Alberta Court of Queen's Bench 2002) http:// www.canlii.org/en/ab/abqb/doc/2002/2002abqb1086/2002abqb1086.html (10 February 2011), Para. 69.
} 
is necessary to examine the rationale behind it. In short -- without being flip -- why would we not want those who may be less able to form rational choices be able to vote? I would submit the concern is rooted in the belief that younger people would make inconsistent or rash decisions in their voting. This could, in turn, increase electoral volatility and begin to destabilize our system. At its face, this is a reasonable concern. However, is there a necessary connection between volatility or rashness in our political decisions and a destabilization of our system? I note that Lawrence LeDuc has argued quite the opposite. The Canadian electorate, he suggests, is extremely difficult to predict. ${ }^{3}$ They exist in a permanent state of political de-alignment, without a close allegiance to one particular party or ideology. Due to this de-alignment a political party's electoral success is subject to a "much greater element of volatility". ${ }^{4}$ In short, the Canadian electorate has been known to suddenly and drastically shift its political preferences regardless of previous ideological connections or policy preferences. Instead, decisions are often based on perception of a single issue or -- more frequently -- a leader. ${ }^{5}$

The issue of volatility is exacerbated by Canada's Single Member Plurality [SMP] voting system. The natural consequence of a multi-party system that selects representatives who only receive a plurality, rather than a majority, of votes in a riding is that the representation of political parties in the legislature will be very detached from their actual popular support. Indeed, there have been numerous occasions where a political party has won a majority of seats in a legislature without winning the most votes in an election. ${ }^{6}$ Further, SMP tends to favor regional parties which appeal to concentrated pockets of support in areas over parties widespread support across the country. ${ }^{7}$ These parties can be highly populist, such as the Reform or Social Credit Parties, or even have the sole purpose of dismantling our federation, as with the Bloc Quebecois. It is not a stretch of the imagination to suggest that the presence of regional parties alone, particularly one with populist leanings, introduce a volatile ingredient into our system. However, neither the de-alignment noted above nor the skewed nature of the election results, volatile though they may be, have resulted in a destabilization of our system. Indeed, LeDuc marvels at what he christened as Canada's "stable de-alignment". 8 It seems unpersuasive, then, that 16 and 17 years would uniquely pose significant danger due to their "volatile" voting methods.

Next we turn to the linked issues of lack of knowledge of our political system and ability to make rational political choices. As an initial matter it is necessary to determine what level of knowledge is necessary or acceptable for responsible involvement in elections. In his ruling Justice Lefsrud mused that 18 year-olds have the benefit of having recently completed high school social studies. ${ }^{9}$ However, Henry Milner has expressed some concerns that high school social studies does not have sufficient funding or emphasis to adequately prepare young people

\footnotetext{
${ }^{3}$ Lawrence LeDuc, "Realignment and Dealignment in Canadian Federal Politics," in Canadian Parties in Transition, Third Edition, ed. Alain-G. Gagnon and A. Brian Tanguay. (Toronto: Broadview Press, 2007$), 167$.

${ }^{4}$ Ibid.

5 ibid., 172-173.

6 John C. Courtney, "Canada's Electoral System," in Canadian Parties in Transition, Third Edition, ed. Alain-G. Gagnon and A. Brian Tanguay. (Toronto: Broadview Press, 2007), 296-297.

7 ibid., 297.

${ }^{8}$ LeDuc, "Realignment and Dealignment in Canadian Federal Politics", 167

${ }^{9}$ Fitzgerald v. Alberta, Para. 71
} 
for civic participation ${ }^{10}$, but does note that the courses are more effective the older the student is. ${ }^{11}$ Milner also suggests that base political knowledge -- such as knowing the Prime Minister's name, the provincial Premiers name, or the leader of another party's name ${ }^{12}--$ is problematically low at all age levels. Once again, let us put this issue in perspective. On its surface, the need for a higher level of knowledge on the part of those who participate in the political system seems obvious. However, we do not consider this a requirement of voting in Canada; no test must be passed and no I.Q. threshold must be met. Rather, there is simply an assumption that we will become more informed citizens as we grow older. Indeed, Milner presents statistical evidence to that effect, but even this evidence does not quite persuade one that in-depth political knowledge is widespread amongst the Canadian electorate. Milner notes that, in one survey, $67 \%$ of those aged 18-29 could answer at most one out of three political knowledge questions. ${ }^{13}$ It is reasonable to assume this result would be similar among 16 and 17 year-olds. However, in the sample as a whole -- noting people of all ages -- fully $46 \%$ of respondents were incapable of answering more than one question ${ }^{14}$; this hardly suggests a well informed electorate. Indeed, Milner also notes that one of the major differences amongst those with little political interest or knowledge is that youth who lack knowledge tend not to vote, whereas older voters tend to vote despite their lack of knowledge. ${ }^{15}$ This raises the heart of the issue, given that we accept that all citizens over 18 can and should be allowed to vote regardless of knowledge of our system, and the fact that many who lack knowledge do, can a lack of knowledge be a valid justification for denying 16 and 17 year-olds the vote? Evidently, political decisions are made based on other factors, which we will now turn to.

At the risk of sounding cynical, I would suggest that the ideal practice of the modern voter, independently seeking out the information available on the parties, leaders and issues of the day, has fallen to the wayside. Rational choice in voting has been replaced, in part, by other methods of decision making. In their writings on American political decision making Arthur Lupia and Matthew McCubbins submit that people are quite capable of making valid and effective decisions with little or no information. ${ }^{16}$ When making a decision we often defer to the information presented to us by others -- based on our perception of another persons reliability, honesty, and knowledge on the subject being discussed -- in order to make up for their own lack of information; as Lupia and McCubbins note: "this is why people turn to financial advisors". ${ }^{17}$ To explain the theory another way: consider when we purchase a new car, we are certainly capable of downloading information on that vehicle, researching similar models made by other companies, comparing statistics on details such as gas mileage, acceleration, etc., but more often than not we defer to the anecdotes and experiences of friends who have driven or purchased a vehicle similar to the model we are considering. We defer our decisions on voting in much the

${ }^{10}$ Henry Milner, "The Problems of Political Drop Outs: Canada in Comparative Perspective," in Canadian Parties in Transition, Third Edition, ed. Alain-G. Gagnon and A. Brian Tanguay. (Toronto: Broadview Press, 2007), 453.

${ }^{11}$ ibid., 454.

12 ibid., 445.

${ }^{13}$ Milner, “The Problems of Political Drop Outs: Canada in Comparative Perspective”, 445.

14 ibid.

${ }^{15}$ Ibid., 443-444.

${ }^{16}$ Arthur Lupia \& Matthew D. Mcubbins, "The Democratic Dilemma: Can Citizens Learn What They Need to Know?" in Readings in American Politics: Analysis and Perspectives, ed. Ken Kollman. (New York: W.W. Norton \& Company, 2010), 369.

${ }^{17}$ Lupia and McCubbins, The Democratic Dilemma: Can Citizens Learn What They Need to Know?", 372. 
same way in Canada. A great deal depends on message. In his work, Stephen Brooks expresses great concern about the influences "spots ads" and the media can have in manipulating voters of any age. Partisan messages are carefully constructed to attract voters across the country into broad "big tent" parties which render party differences far less important. ${ }^{18}$ Furthermore, much of a campaign is based on the how a particular leader is perceived by the public as a whole as he delivers that message. ${ }^{19}$ Recognizing that the public make fair and intelligent decisions, with little or no relevant information, through their perceptions of a message or through discussions with others, its seems difficult to accept that 16 and 17 year olds would be incapable of doing the same. Indeed, as Milner notes, 16 and 17 year olds may be more likely to form opinions -because of the influence of their parents or teachers -- than 18 year olds. ${ }^{20}$ Again, the "common sense" justification cannot stand up when placed in perspective.

Within the Canadian context, the government can only deny a person's rights when the denial can be demonstrably justified. When placed in context with the rest of the Canadian population the justifications for denying 16 and 17 year olds the right to vote simply fail. While we can accept that 16 and 17 year old may bring some increased volatility to the political system, there is little reason to believe that that volatility will lead to any sort de-stabilization. Nor should we be persuaded that their lack of knowledge or rationality is worrisome when we consider that most political decisions are made by many voters based on message or perceptions from 30 second television ads. There is a great deal of issues that one may take with the Canadian political system. The one thing that we may be proud of is that our system requires a strong justification before we are able to deny a person a right as fundamental as the right to vote.

\footnotetext{
${ }^{18}$ Janine Brodie \& \& Jane Jenson, "Piercing the Smokescreen: Stability and Change in Brokerage Politics" in Canadian Parties in Transition, Third Edition, ed. Alain-G. Gagnon and A. Brian Tanguay (Toronto: Broadview Press, 2007), 44-49; SEE ALSO: Thomas Flanagan, "Campaign Strategy: Triage and the Concentration of Resources" in Election, ed. Heather MacIvor (Toronto: Emond Montgomery Publications Limited, 2010) 165-170; Stephen Brooks, "Television Advertising by Political Parties: Can Democracy Survive it?" in Canadian Parties in Transition, Third Edition, ed. Alain-G. Gagnon and A. Brian Tanguay (Toronto: Broadview Press, 2007), 362-367. ${ }^{19}$ Flanagan, "Campaign Strategy: Triage and the Concentration of Resources", 167-169.

${ }^{20}$ Milner, "The Problems of Political Drop Outs: Canada in Comparative Perspective", 458.
} 


\section{Bibliography}

Brodie, Janine \& Jane Jenson. "Piercing the Smokescreen: Stability and Change in Brokerage Politics." Canadian Parties in Transition, Third Edition. Edited by Alain-G. Gagnon and A. Brian Tanguay, 33-53 Toronto: Broadview Press, 2007.

Brooks, Stephen. “Television Advertising by Political Parties: Can Democracy Survive it?" in Canadian Parties in Transition, Third Edition. Edited by Alain-G. Gagnon and A. Brian Tanguay, 355-369. Toronto: Broadview Press, 2007.

Courtney, John C. "Canada's Electoral System." in Canadian Parties in Transition, Third Edition. Edited by Alain-G. Gagnon and A. Brian Tanguay, 279- 301. Toronto: Broadview Press, 2007.

Flanagan, Thomas. "Campaign Strategy: Triage and the Concentration of Resources." in Election. Edited by Heather MacIvor, 155-172. Toronto: Emond Montgomery Publications Limited, 2010.

LeDuc, Lawrence. "Realignment and Dealignment in Canadian Federal Politics." in Canadian Parties in Transition, Third Edition. Edited by Alain-G. Gagnon and A. Brian Tanguay, 163-196. Toronto: Broadview Press, 2007.

Lupia, Arthur \& Matthew D. Mcubbins. Excerpt from "The Democratic Dilemma: Can Citizens Learn What They Need to Know? in Readings in American Politics: Analysis and Perspectives. Edited by Ken Kollman, 365-377. New York: W.W. Norton \& Company, 2010.

Milner, Henry. "The Problems of Political Drop Outs: Canada in Comparative Perspective." in Canadian Parties in Transition, Third Edition. Edited by Alain-G. Gagnon and A. Brian Tanguay, 437-465 Toronto: Broadview Press, 2007.

Fitzgerald v. Alberta. 331 SCC 1086 (Alberta Court of Queen's Bench 2002) http:// www.canlii.org/en/ab/abqb/doc/2002/2002abqb1086/2002abqb1086.html (10 February 2011)

Sauvé v. Canada (Chief Electoral Officer), SCC 68 (Supreme Court of Canada 2002) http:// www.canlii.org/en/ca/scc/doc/2002/2002scc68/2002scc68.html4 (10 February 2011) 